\title{
USING TECHNOLOGY AGAINST THEFT AND FORGERY OF CULTURAL HERITAGE GOODS
}

\author{
Mahmut AYDIN \\ Assistant Prof. Dr. \\ Archaeologist/Archaeometrist \\ Batman University-Department of Archaeology Batman-Turkey \\ mahmut.aydin@batman.edu.tr
}

DOI:10.5901/mjss.2014.v5n22p32

\begin{abstract}
The aim of this study is to evaluate problems of museums and collectors that buy cultural heritage objects from individuals without asking a certificate of authenticity. Keeping collection of museums authentic is going to be more difficult because of developed replication technologies used by forgers who want to sell fake objects to museums and collectors. Moreover because of ill intended museum personnel who want to replace authentic objects with fake. In order to overcome such problems, it is necessary to get chemical composition of cultural heritage objects. Cultural heritage objects are sensitive and unique so the technique that is going to be used in analysis of such objects must be non-invasive. Portable Energy Dispersive $X$-Ray Florescence (P-EDXRF) lets scientists analyze cultural heritage in a non-destructive way. Determination of chemical composition of objects in quite short times such as 30 seconds per analysis) and seeing qualitative and quantitative results simultaneously is possible. Results of P-EDXRF can be used in determination of authenticity, provenance studies, getting information about production technology of analyzed objects and for restoration purposes. Moreover, P-EDXRF lets scientist make multiple analyzes, especially from big objects as it is non-invasive, fast and cheap. Besides, due to spectrometers being as light as $2 \mathrm{~kg}$, it is portable and enables in situ analyses in museums or wherever objects are being kept. Characterization of cultural objects let museums keep chemical composition of objects in the inventory books. Chemical composition of object would act as the fingerprint of the objects. Therefore P-EDXRF results can be used to determine if an authentic object in the collection was changed with a fake one or not. These can be done by comparing new chemical composition of suspected existing cultural heritage objects and chemical composition that record in inventory book. Moreover in case of a museum robbery, recorded analysis results of stolen objects can be used to prove authenticity of recovered items. Majority of the time, after museum robberies fakes of stolen objects are made by forgers and are tried to be sold to collectors or museums. $P$ EDXRF also used for restoration with the aim of detecting the chemical composition of the artifact. In authenticity studies SEMEDX also is widely used to determine chemical composition and matrix morphology of the objects.
\end{abstract}

Key words: Cultural heritage, Museums collections, Portable X Ray Florescence, Authenticity, Counterfeit

\section{Introduction}

Production of fake objects started in Renaissance Era (16th century AD) in Padua, Italy. The Italian Renaissance saw a widespread revival of interest in the classical world, Greek and Roman. Desire for Greek and Roman artifacts fed market not only for items of antiquity, but for contemporary creations based on ancient themes. Almost as quickly as this desire emerged, forgeries of antiquities and coins were produced to feed the market. As early as 1555 AD the Italian Numismatist Enea Vico included a section on the issue of forgeries in his book named "Discorsi sopra le Medaglie degli Antichi". The warnings of Vico read much like the warnings one might hear today about re-engraving or tooling cast, modern die struck specimens etc. (Sayles 2000).

As the world became increasingly scientific in the 17th and 18th centuries, the nature of forgeries changed. The rise of specialization during this period presented to forgers of the day an irresistible challenge. For the first time in the long history of making fakes, a conscious effort was made to produce items specifically for collectors' consumptions (Sayles 2000).

In the post renaissance, the challenge between forger and collector was really begun. For this period an important article was published by Spier and Kagan (2000), related with famous forgery of ancient coins in eighteenth century Rome. Forgers of the 19th century may not have had access to all of the technological aids that exist today. But anyhow they produced remarkable works. Even today, fakes that were made a century ago are being discovered (Sayles 2000). 
The most notable change in the nature of forgeries during the 20th century was the use of advanced technology to make precision copies of cultural heritage objects.

Due to the advances in replication technology, the situation became more complex in the 21th century. Because fake objects started to be sold directly to the museums and collectors. Beside this, authentic objects of museum collections started to be replaced with fakes.

In Turkey and other alike countries, authenticity certificate is not requested when buying cultural heritage goods. Authenticity checks made only by visual inspection is not enough for 21 th century replication technology. In USA and many EU countries there are companies that issues certificate of authenticity for cultural heritage materials.

Fakes of metal objects and paintings are more commonly made mostly because they cannot be directly dated. Baked clay and organic material can be dated with radiocarbon and thermoluminescence dating techniques (Aitken 1985; Taylor 1987). Therefore fakes of these objects are found less than metals and paintings.

In the all developed countries non-invasive archaeometric techniques are commonly used to determine authenticity of cultural heritage objects (Hida et al. 2007; Pauna 2010).

Chemical composition of artifacts can be accepted as the fingerprint of these objects. This can be obtained by non-invasive archaeometric techniques and result of analyses can be recorded in the inventory notebooks. In case of any suspicious situations where authentic object could be replaced with a fake one, analyses can be done on the said objects and results can be compared with the recorded fingerprint and the problem can be solved.

In 1996 a very precious object, golden winged seahorse brooch dating to the Lydian Age hosted by the museum Uşak, Turkey was replaced with a fake one by the manager of the museum, and was later tried to be sold for $€ 2500000$. Authenticity of the replaced fake winged seahorse was questioned for a long time and at the end it was understood that the original artefact was replaced with a fake one while the authentic was stolen. Beside this case, many paintings from the Ankara State Museum of Paintings and Sculptures (Turkey)are suspected to have been replaced with fakes. But their authenticity or lack thereof could not be proven yet. All of these problems could be solved in a timely manner if the objects were analyzed and their chemical compositions were recorded.

Because trade of cultural heritage is forbidden within and outside of the Turkey and similar countries, individuals sell any cultural heritage objects found to museums and collectors. But this situation is also an opportunity for forgers who wish to sell fake objects. By using non-invasive archaeometrical methods against forgery, museums and collectors can get ahead of new reproduction technologies and protect the authenticity of their collections.

\section{Method}

\section{Material and Method}

Cultural heritage objects are rare and sensitive so their analysis should be non-invasive. The most common non-invasive technique used in analyses of cultural heritage objects is Energy dispersive X-Ray Florescence Spectrometer (P-EDXRF). This technique allow scientists to analyze objects without removing pieces from object (non-invasive), and in situ analysis is possible because the spectrometer (Figure 1) is portable (with a weight of $2 \mathrm{~kg}$ ), multiple analysis from same object is possible because of it is non-invasive and analysis results can be obtained within 30 to 60 seconds (Ardid et. al. 2004; Hida et. al.2007). Results of P-EDXRF are given as qualitative and quantitative with a detection limit of 10-50 per particle million (ppm). It is also possible to get spectrums of analysis from the spectrometer.

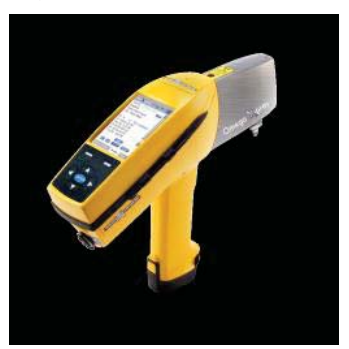

Figure 1: Omega, Portable Energy Dispersive X-Ray Florescence (P-EDXRF) Spectrometer 
By using P-EDXRF, chemical fingerprint of cultural heritage objects made of precious metal alloys, clay, paint layers and marble/stone can be determined. Therefore using P-EDXRF became a popular technique in the analysis of cultural heritage objects.

P-EDXRF spectrometer can be used for deciding on the pre-restoration strategy of intervention on the artifact to be restored with the aim of detecting the chemical composition of the artifact. It is also used often for recording the changes on the chemical composition of the artifact during restoration so that analysis mostly done before and after restoration.

\section{Keeping Collections Authentic}

There are two major risks that threat collections; first of these threats is obtaining fake objects and the second is replacement of an authentic object belonging to the collection with a fake one.

\section{Protection of Collections from Fake Objects}

Museums collections contain very precious and rare objects. Therefore their authenticity should be protected from fake objects which have low artistic value. Furthermore, usually not even their material is as precious as their originals.

Baked clay objects can be dated by using luminance dating techniques (Aitken 1985). Organic objects can be dated by using radiocarbon dating (Taylor 1987). However metal objects and paintings cannot be directly dated therefore the difference in their manufacture technology compared to the authentic objects can be used to determine their authenticity.

Ore processing techniques leave many traces behind. Through chemical composition determination of metal objects, these traces can be followed. In order to evaluate analysis results, scientists should have enough data from both fake and authentic objects, so a comparison of the analysis results is possible.

\section{Silver objects}

By using P-EDXRF silver coins of known authenticity obtained from excavation were analyzed in order to use their results as reference. Beside these, data, from many articles and books can be used as reference material for silver coins in order to evaluate major and minor elements from the data belonging to coins of suspected authenticity (Walker 1976; 1979; Aydin 2013; Fleming 1975).

Coins from Roman Imperial Age that have been tried to be sold to the Erzurum/Turkey Museum have aroused suspicions. After analysis of the suspicious coins of Vespasian (69-79 A.D.), Hadrian (117-138 A.D.), Severus Alexander (222-235 A.D.), Gordian II (238 A.D.) and Marcia Otacilla Severa (244-249 A.D.) were carried out, results were compared with that of authentic silver coins coming from excavation (Table 1). Interpretation of analysis results of Vespasian, Severus Alexander, Gordian II and Otacilla Severa were quite simple because the chemical composition of coins turned out to be too far from authentic coins'. Chemical composition of these coins mainly should be silver (Ag) but analysis results clearly show that the coins were made of Copper (Cu), Nickel (Ni) and Zink (Zn) alloy. This alloy is sometimes called German silver and is commonly used in todays metallurgy and production of fake silver coins and other objects as nickelprovides a color close to the sense of silver (Gürü \& Yalçın 2012).
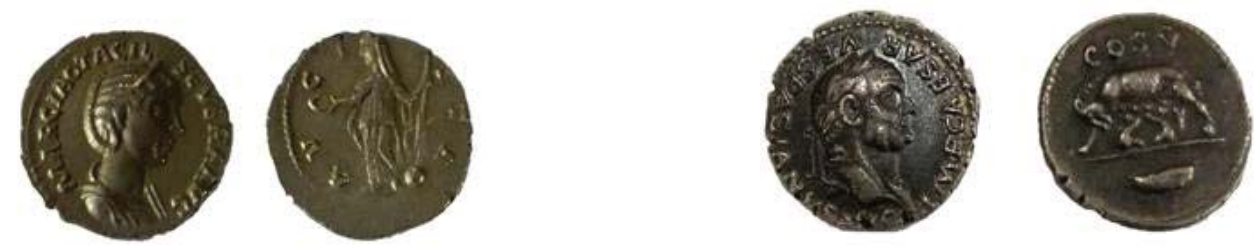

Figure 2: Fake coin of Marcia Otacilla Severa (left) and Vespasian (right) made of German silver

Suspicious coins of Hadrian made of silver and average main element silver $(\mathrm{Ag})$ is $97 \%$ which nearly overlaps with average $95 \% \mathrm{Ag}$ of authentic Hadrian silver coins. However minor elements Bismuth $(\mathrm{Bi})$ and $\mathrm{Lead}(\mathrm{Pb})$ of these Hadrian coins are far from authentic silver coins' results (Table 1). $90 \%$ of authentic silver coins including Bi and not none of authentic silver coin including lead (Pb) fewer than 0, 005 \% (Aydin 2013; Fleming 1975). Therefore suspicious Hadrian coins are also fake. 


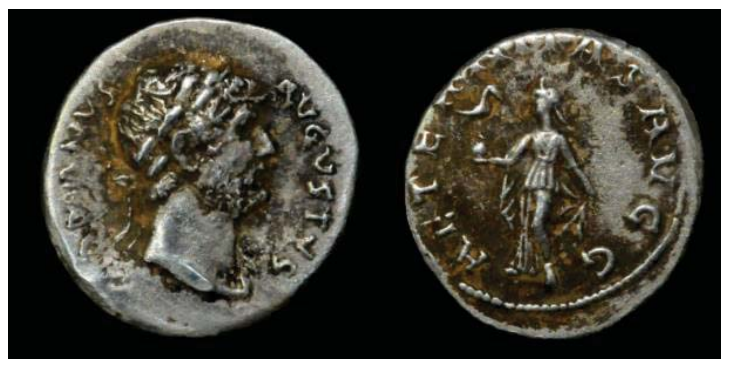

Figure 3: Fake coin of Hadrian made of silver $(\mathrm{Ag})$

\section{Gold Coins}

By using same methodology that was used for silver coins, authenticity of gold coins can also be determined. Beside this, in order to determine authenticity of gold coins and objects it is necessary to know modern gold chemical composition/fingerprint. Because qualitative and quantitative results of modern gold help us to interpret results of suspicious gold coins/objects (Aydın \& Mutlu 2012).

Suspicious coins dated to Byzantium Age was tried to be sold to a collector in Ankara/Turkey. In order to determine their authenticity modern gold (Table 2) and suspicious coins (Table 2) were analyzed by using PEDXRF. Authentic coins coming from excavation and belonging to the same emperor with the suspicious coins were also analyzed with same EDXRF (Table 2). Result of modern gold, suspicious coins and authentic coins were compared and evaluated.

Major elements of suspicious coins dated to Maurice Tiberius period have average Au $81,77 \%$ and $\mathrm{Ag} 8,02 \%$. Authentic coins of same emperor have $98,88 \% \mathrm{Au}$ and 1, 58\% Ag. Major elements of suspicious and authentic coins are far from each other (Table 2). Purity of the coins are determined by the authority in antiquity, so chemical composition do not tend to change within the emperor's period so much.
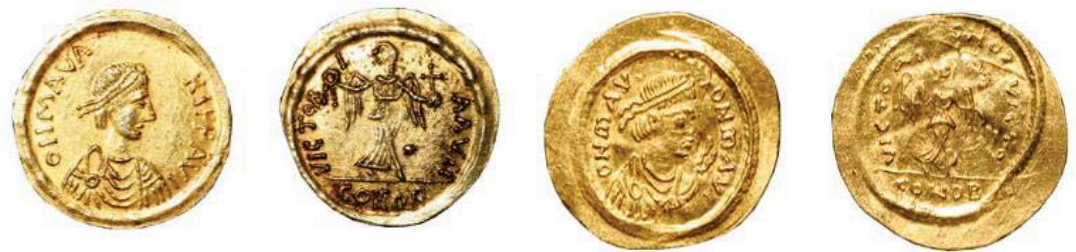

Figure 4: Fake coin (left Inv. No 5) and authentic coin (right Inv. 2-1) of Maurice Tiberius

Minor elements of suspicious coins (Table 2) and modern gold (Table 3 ) have similarity in terms of Zinc (Zn) and Molybdenum (Mo). Suspicious coins' average values for Mo 0, 029\% and Zn 0, 22\% are very close to the minor elements of modern coins $\mathrm{Zn} 0,14 \%$ and Mo $0,017 \%$.

When the results of chemical fingerprint of suspicious gold coins, authentic gold coins and modern gold are evaluated; suspicious gold coins of Maurice Tiberius are counterfeit with high probability, in terms of major and minor elements (Table 2 and Table 3).

Recording of Chemical Fingerprint of Cultural Heritage Objects Against Replacement of Fake Objects with Authentic Objects

Police applications can be taken as example for this application. For security, fingerprints of people are taken and recorded. In case of a crime, records are compared with fingerprint taken from crime area.

The situation is same for cultural heritage. Chemical fingerprints of cultural heritage objects must be determined and recorded in secure places. If analysis are made from big objects, the analysis location should be identified 
on photos (Figure 5), all minor and major elements should be recorded (Table 4) including spectrum of analysis and properties of spectrometer.

In case of any suspected situation where authentic objects could be replaced with a fake, chemical fingerprint of suspicious objects can be determined and compared with recorded analysis result of authentic object. Analysis of suspected artefact must be done with same spectrometer or with a spectrometer that has the same properties. If the recorded and new analysis results are very far from each other and their spectrums support this it is clear that the object have been replaced with fake one.
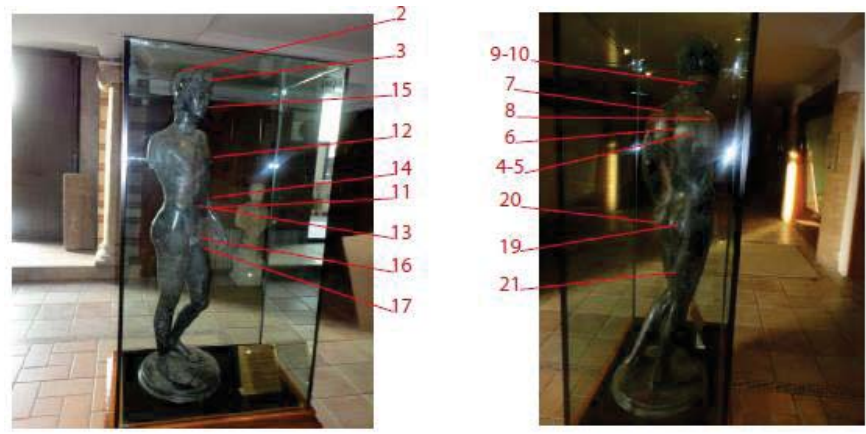

Figure 5: P-EDXRF analysis places from different points of sculpture

Another benefit of recording analysis results of cultural heritage objects is using these results when police recovers stolen objects. In order to prove that the found object is in fact the stolen object, analysis results can be used. This is because after famous objects are stolen from museums, fakes of them are introduced to the market. Therefore it is very difficult to prove if the found object is the stolen authentic one or not. This is one of the big issues that INTERPOL deals with.

\section{Discussion/Conclusion}

In 21 st century depending to reproduction technology we meet examples of trade of fake artifacts to museums and collectors almost every day. Replacement of original artifacts with fake ones or stealing from museums is rare but possible. This situation can only be prevented thanks to the use of advanced spectrometers. Hence science laboratories should be established in museums and expert archaeometrists should be employed.

In order to determine authenticity of coins Scanning Electron Microscopy adopted with Energy Dispersive X-Ray (SEMEDX) can also be used. As the liquid solidifies, Cu rich regions may form dendrites. If the alloy is freshly made, dendrites are stable. As time passes, Cu will diffuse into the alloy again. Because of SEM-EDX allows taking image and making analysis of dendrites and matrix of objects, we can determine if the alloy has been freshly made or not. SEM-EDX is a noninvasive technique for small objects around $3 \mathrm{~cm}$ but bigger objects may not fit in the sample holder of SEM-EDX (Demortier 2003; Aydın 2013).

Non-invasive archaeometric techniques have important role in keeping collections authentic. These techniques protect collections from forgers and internal theft. Using of these techniques also help scientist to prove that the found object is the stolen one. This let museums to get their stolen objects back.

\section{References}

Ardid M., Ferrero J., L., JuanesaD., Lluch J.L. \&Rolda C. (2004). Comparison of total-reflection X-ray fluorescence, static and portable energy dispersive X-ray fluorescence spectrometers for art and archeometry studies. Spectrochimica Acta Part B 59, 1586.

Aydın, M. (2013), Authenticity of Roman Imperial Age Silver Coins Using Non-destructive Archaeometric Techniques, Unpublished Doctorate Thesis, METU-FBE, Ankara.

Aydın, M. \& Mutlu, S. (2013). Bizans Dönemine ait Altın Sikke Orijinalliğinin Tespitinde Tahribatsız Arkeometrik ve Görsel Analiz Yöntemlerinin Kullanılması. In A.A. Akyol ve K. Özdemir (Edt) Türkiye'de Arkeometrinin Ulu Çınarları Prof. Dr. Ay Melek Özer ve Prof. Dr. Şahinde Demirci'ye Armağan (pp 97-105). Homer Kitabevi, İstanbul. 
Aitken M., J., (1985). Radiocarbon Dating an Archaeological Perspective. Academic Press Inc. Orlando-Florida.

Demortier G. (2003). PIXE and PIGE non destructive analysis of gold, silver and bronze Coins. Numismatic \& Technology: Questions and Answers symposium proceedings, SPVDruck, Vienna, pp 37-49.

Hida M., Mitsui T \& Minami Y. (1997). Forensic investigation of counterfeit coins. Forensic Sci Int 89, 21-26.

Gürü M \& Yalçın H. (2012). Malzeme Bilgisi. Palme Yayıncılık, Türkiye.

Fleming J. S., (1975). Authenticity in art, the scientific detection of forgery. The Institute of Physics Press, London.

Pauna C., Constantinescu B., Constantin F., Bugoi R., Stan D., Vasilescu A., (2010). Archaeometrical studies using X-ray fluorescence methods. AIP Conf. Proc., Volume 1231, 187-188.

Sayles G. W. (2000). Classical deception counterfeits, forgeries and reproduction of ancient coins. Krause Publication, USA. Speir J., Kagan J. (2000). Sir Charles Frederick and the forgery of ancient coins in eighteenth-century Rome. Journal of the History of Collections, New York.

Taylor R., E., (1987). Thermoluminance dating. Harcourt Brace Jovanovich Publishers, London.

Walker D. R. (1976). The metrology of the Roman silver coinage part I, from Augustus to Domitian. Publications, Supplementary Series 5, London.

Walker D. R. (1977). The metrology of the Roman silver coinage part II from Nerva to Commodus. BAR Publications, Supplementary Series 22. London.

Walker D. R. (1978). The metrology of the Roman silver coinage. Part III, from Pertinax to Uranius Antoninus, BAR

Publications, Supplementary Series 40. London.

\section{Tables}

Table 1: P-EDXRF analysis results of Suspicious and Authentic Silver coins.

\begin{tabular}{|c|c|c|c|c|c|c|c|c|c|c|c|c|c|}
\hline Object & $\begin{array}{l}\text { Analiysis } \\
\text { Side }\end{array}$ & $\mathrm{Ti}$ & $\mathrm{Fe}$ & $\mathrm{Ni}$ & $\mathrm{Cu}$ & $\mathrm{Zn}$ & $Z r$ & Mo & $\mathrm{Ag}$ & $\mathrm{Pt}$ & $\mathrm{Pb}$ & $\mathrm{Bi}$ & Results \\
\hline $\begin{array}{l}\text { Suspicious Vespasian } \\
\text { Coin } 1\end{array}$ & Obverse & ND & $\begin{array}{l}0 \\
21\end{array}$ & $\begin{array}{l}19, \\
77\end{array}$ & $\begin{array}{l}69, \\
4\end{array}$ & $\begin{array}{l}9 \\
93\end{array}$ & ND & $\begin{array}{l}0, \\
023\end{array}$ & ND & $\begin{array}{l}0 \\
041\end{array}$ & $\begin{array}{l}0 \\
069\end{array}$ & ND & $\begin{array}{l}\text { Fake } \\
\text { Made of } \\
\text { German } \\
\text { Silver }\end{array}$ \\
\hline $\begin{array}{l}\text { Suspicious Vespasian } \\
\text { Coin } 1\end{array}$ & Reverse & ND & $\begin{array}{l}0 \\
16\end{array}$ & $\begin{array}{l}19, \\
19\end{array}$ & $\begin{array}{l}68 \\
7\end{array}$ & $\begin{array}{l}11 \\
84\end{array}$ & ND & $\begin{array}{l}0, \\
025\end{array}$ & ND & $\begin{array}{l}0 \\
054\end{array}$ & $\begin{array}{l}0 \\
057\end{array}$ & ND & $\begin{array}{l}\text { Fake } \\
\text { Made of } \\
\text { German } \\
\text { Silver }\end{array}$ \\
\hline $\begin{array}{l}\text { Suspicious Vespasian } \\
\text { Coin } 2\end{array}$ & Obverse & ND & $\begin{array}{l}0 \\
3\end{array}$ & $\begin{array}{l}19 \\
8\end{array}$ & $\begin{array}{l}67 \\
4\end{array}$ & $\begin{array}{l}12, \\
33\end{array}$ & ND & $\begin{array}{l}0, \\
027\end{array}$ & ND & $\begin{array}{l}0 \\
045\end{array}$ & $\begin{array}{l}0 \\
047\end{array}$ & ND & $\begin{array}{l}\text { Fake } \\
\text { Made of } \\
\text { German } \\
\text { Silver }\end{array}$ \\
\hline $\begin{array}{l}\text { Suspicious Vespasian } \\
\text { Coin } 2\end{array}$ & Reverse & ND & $\begin{array}{l}0 \\
19\end{array}$ & $\begin{array}{l}19, \\
36\end{array}$ & $\begin{array}{l}66, \\
9\end{array}$ & $\begin{array}{l}13 \\
37\end{array}$ & ND & $\begin{array}{l}0, \\
028\end{array}$ & ND & $\begin{array}{l}0 \\
055\end{array}$ & $\begin{array}{l}0 \\
036\end{array}$ & ND & $\begin{array}{l}\text { Fake } \\
\text { Made of } \\
\text { German } \\
\text { Silver }\end{array}$ \\
\hline $\begin{array}{l}\text { Suspicious Hadrian } \\
\text { Coin } 1\end{array}$ & Obverse & ND & $\begin{array}{l}0 \\
25\end{array}$ & ND & $\begin{array}{l}1 \\
79\end{array}$ & ND & ND & ND & $\begin{array}{l}97 \\
95\end{array}$ & ND & $\begin{array}{l}0 \\
004\end{array}$ & ND & $\begin{array}{l}\text { Fake } \\
\text { Made of } \\
\text { Modern } \\
\text { Silver }\end{array}$ \\
\hline
\end{tabular}




\begin{tabular}{|c|c|c|c|c|c|c|c|c|c|c|c|c|c|c|}
\hline $\begin{array}{l}\text { Suspicious } \\
\text { Coin } 2\end{array}$ & Hadrian & Obverse & $\begin{array}{l}0 \\
4\end{array}$ & $\begin{array}{l}0 \\
29\end{array}$ & ND & $\begin{array}{l}1 \\
78\end{array}$ & ND & ND & ND & $\begin{array}{l}97 \\
43\end{array}$ & ND & $\begin{array}{l}0, \\
0041\end{array}$ & ND & $\begin{array}{l}\text { Fake } \\
\text { Made of } \\
\text { Modern } \\
\text { Silver }\end{array}$ \\
\hline $\begin{array}{l}\text { Suspicious } \\
\text { Coin } 3\end{array}$ & Hadrian & Obverse & ND & $\begin{array}{l}1 \\
09\end{array}$ & ND & $\begin{array}{l}2, \\
1\end{array}$ & ND & $\begin{array}{l}0, \\
01\end{array}$ & ND & $\begin{array}{l}96, \\
67\end{array}$ & ND & $\begin{array}{l}0, \\
0042\end{array}$ & ND & $\begin{array}{l}\text { Fake } \\
\text { Made of } \\
\text { Modern } \\
\text { Silver }\end{array}$ \\
\hline $\begin{array}{l}\text { Suspicious } \\
\text { Coin } 4\end{array}$ & Hadrian & Obverse & ND & $\begin{array}{l}0 \\
83\end{array}$ & ND & $\begin{array}{l}1 \\
97\end{array}$ & ND & $\begin{array}{l}0 \\
01\end{array}$ & ND & $\begin{array}{l}97 \\
09\end{array}$ & ND & $\begin{array}{l}0, \\
0042\end{array}$ & ND & $\begin{array}{l}\text { Fake } \\
\text { Made of } \\
\text { Modern } \\
\text { Silver }\end{array}$ \\
\hline $\begin{array}{l}\text { Suspicious } \\
\text { Coin } 5\end{array}$ & Hadrian & Obverse & $\begin{array}{l}0 \\
39\end{array}$ & $\begin{array}{l}1 \\
37\end{array}$ & ND & $\begin{array}{l}1 \\
67\end{array}$ & ND & $\begin{array}{l}0, \\
05\end{array}$ & ND & $\begin{array}{l}96 \\
26\end{array}$ & ND & $\begin{array}{l}0, \\
0044\end{array}$ & ND & $\begin{array}{l}\text { Fake } \\
\text { Made of } \\
\text { Modern } \\
\text { Silver }\end{array}$ \\
\hline $\begin{array}{l}\text { Suspicious } \\
\text { Alexander }\end{array}$ & Severus & Obverse & ND & $\begin{array}{l}0 \\
16\end{array}$ & $\begin{array}{l}19, \\
28\end{array}$ & $\begin{array}{l}65, \\
8\end{array}$ & $\begin{array}{l}14 \\
45\end{array}$ & ND & $\begin{array}{l}0 \\
026\end{array}$ & ND & $\begin{array}{l}0 \\
049\end{array}$ & ND & ND & $\begin{array}{l}\text { Fake } \\
\text { Made of } \\
\text { German } \\
\text { Silver }\end{array}$ \\
\hline $\begin{array}{l}\text { Suspicious G } \\
\text { Coin }\end{array}$ & Gordian II & Obverse & ND & $\begin{array}{l}0 \\
16\end{array}$ & $\begin{array}{l}19, \\
06\end{array}$ & $\begin{array}{l}67 \\
4\end{array}$ & $\begin{array}{l}13 \\
11\end{array}$ & ND & ND & ND & ND & $\begin{array}{l}0, \\
029\end{array}$ & ND & $\begin{array}{l}\text { Fake } \\
\text { Made of } \\
\text { German } \\
\text { Silver }\end{array}$ \\
\hline $\begin{array}{l}\text { Suspicious } \\
\text { Severa Coin } 1\end{array}$ & 1 Otacilla & Obverse & ND & $\begin{array}{l}0, \\
17\end{array}$ & $\begin{array}{l}20 \\
7\end{array}$ & $\begin{array}{l}72 \\
4\end{array}$ & $\begin{array}{l}6 \\
67\end{array}$ & ND & $\begin{array}{l}0 \\
024\end{array}$ & ND & ND & $\begin{array}{l}0, \\
014\end{array}$ & ND & $\begin{array}{l}\text { Fake } \\
\text { Made of } \\
\text { German } \\
\text { Silver }\end{array}$ \\
\hline $\begin{array}{l}\text { Suspicious } \\
\text { Severa Coin } 2\end{array}$ & $2^{\text {Otacilla }}$ & Obverse & ND & $\begin{array}{l}0 \\
14\end{array}$ & $\begin{array}{l}19, \\
77\end{array}$ & $\begin{array}{l}65, \\
5\end{array}$ & $\begin{array}{l}14 \\
38\end{array}$ & ND & $\begin{array}{l}0 \\
03\end{array}$ & ND & $\begin{array}{l}0, \\
057\end{array}$ & $\begin{array}{l}0, \\
024\end{array}$ & ND & $\begin{array}{l}\text { Fake } \\
\text { Made of } \\
\text { German } \\
\text { Silver }\end{array}$ \\
\hline $\begin{array}{l}\text { Authentic } \\
\text { Coin } 1\end{array}$ & Vespasian & Obverse & ND & ND & ND & $\begin{array}{l}3 \\
61\end{array}$ & ND & ND & ND & $\begin{array}{l}95 \\
78\end{array}$ & ND & $\begin{array}{l}0, \\
5687\end{array}$ & $\begin{array}{l}0 \\
041\end{array}$ & $\begin{array}{l}\text { Authentic } \\
\text { From } \\
\text { Excavation }\end{array}$ \\
\hline $\begin{array}{l}\text { Authentic V } \\
\text { Coin } 2\end{array}$ & Vespasian & Obverse & ND & $\begin{array}{l}0, \\
05\end{array}$ & ND & $\begin{array}{l}1, \\
84\end{array}$ & ND & ND & ND & $\begin{array}{l}95 \\
94\end{array}$ & ND & $\begin{array}{l}2, \\
0807\end{array}$ & $\begin{array}{l}0, \\
082\end{array}$ & $\begin{array}{l}\text { Authentic } \\
\text { From } \\
\text { Excavation }\end{array}$ \\
\hline $\begin{array}{l}\text { Authentic V } \\
\text { Coin } 3\end{array}$ & Vespasian & Obverse & ND & ND & ND & $\begin{array}{l}2 \\
32\end{array}$ & ND & ND & ND & $\begin{array}{l}96 \\
92\end{array}$ & ND & $\begin{array}{l}0, \\
7095\end{array}$ & $\begin{array}{l}0 \\
053\end{array}$ & $\begin{array}{l}\text { Authentic } \\
\text { From } \\
\text { Excavation }\end{array}$ \\
\hline $\begin{array}{l}\text { Authentic V } \\
\text { Coin } 4\end{array}$ & Vespasian & Obverse & ND & ND & ND & $\begin{array}{l}3 \\
36\end{array}$ & ND & ND & ND & $\begin{array}{l}96 \\
32\end{array}$ & ND & $\begin{array}{l}0, \\
2752\end{array}$ & $\begin{array}{l}0 \\
045\end{array}$ & $\begin{array}{l}\text { Authentic } \\
\text { From } \\
\text { Excavation }\end{array}$ \\
\hline $\begin{array}{l}\text { Authentic V } \\
\text { Coin } 5\end{array}$ & Vespasian & Obverse & ND & $\begin{array}{l}0, \\
05\end{array}$ & ND & $\begin{array}{l}3 \\
92\end{array}$ & ND & ND & ND & $\begin{array}{l}95, \\
02\end{array}$ & ND & $\begin{array}{l}0, \\
8566\end{array}$ & $\begin{array}{l}0, \\
046\end{array}$ & $\begin{array}{l}\text { Authentic } \\
\text { From } \\
\text { Excavation }\end{array}$ \\
\hline
\end{tabular}




\begin{tabular}{|c|c|c|c|c|c|c|c|c|c|c|c|c|c|}
\hline $\begin{array}{l}\text { Authentic Hadrian Coin } \\
1\end{array}$ & Obverse & ND & ND & ND & ND & ND & ND & ND & $\begin{array}{l}95 \\
2\end{array}$ & ND & $\begin{array}{l}0 \\
8265\end{array}$ & $\begin{array}{l}0, \\
082\end{array}$ & $\begin{array}{l}\text { Authentic } \\
\text { From } \\
\text { Excavation }\end{array}$ \\
\hline $\begin{array}{l}\text { Authentic Hadrian Coin } \\
2\end{array}$ & Obverse & ND & ND & ND & ND & ND & ND & ND & $\begin{array}{l}97 \\
21\end{array}$ & ND & $\begin{array}{l}0 \\
4531\end{array}$ & $\begin{array}{l}0 \\
268\end{array}$ & $\begin{array}{l}\text { Authentic } \\
\text { From } \\
\text { Excavation }\end{array}$ \\
\hline $\begin{array}{l}\text { Authentic Hadrian Coin } \\
3\end{array}$ & Obverse & ND & ND & ND & ND & ND & ND & ND & $\begin{array}{l}96 \\
99\end{array}$ & ND & $\begin{array}{l}0 \\
4485\end{array}$ & $\begin{array}{l}0 \\
294\end{array}$ & $\begin{array}{l}\text { Authentic } \\
\text { From } \\
\text { Excavation }\end{array}$ \\
\hline $\begin{array}{l}\text { Authentic Hadrian Coin } \\
4\end{array}$ & Obverse & ND & ND & ND & ND & ND & ND & ND & $\begin{array}{l}96, \\
06\end{array}$ & $\begin{array}{l}0 \\
044\end{array}$ & $\begin{array}{l}1 \\
2554\end{array}$ & $\begin{array}{l}0 \\
08\end{array}$ & $\begin{array}{l}\text { Authentic } \\
\text { From } \\
\text { Excavation }\end{array}$ \\
\hline $\begin{array}{l}\text { Authentic Hadrian Coin } \\
5\end{array}$ & Obverse & ND & ND & ND & ND & ND & ND & ND & $\begin{array}{l}93, \\
48\end{array}$ & ND & $\begin{array}{l}1 \\
1265\end{array}$ & $\begin{array}{l}0 \\
176\end{array}$ & $\begin{array}{l}\text { Authentic } \\
\text { From } \\
\text { Excavation }\end{array}$ \\
\hline $\begin{array}{l}\text { Authentic Hadrian Coin } \\
6\end{array}$ & Obverse & $\begin{array}{l}0, \\
3\end{array}$ & ND & ND & ND & ND & ND & ND & $\begin{array}{l}92, \\
71\end{array}$ & ND & $\begin{array}{l}1 \\
2646\end{array}$ & $\begin{array}{l}0 \\
18\end{array}$ & $\begin{array}{l}\text { Authentic } \\
\text { From } \\
\text { Excavation }\end{array}$ \\
\hline
\end{tabular}

Table 2: Suspicious and Authentic gold coins of Maurice Tiberius

\begin{tabular}{|c|c|c|c|c|c|c|c|c|c|c|c|c|c|c|c|c|}
\hline $\begin{array}{l}\text { Inv. } \\
\text { No }\end{array}$ & $\begin{array}{l}\text { Empero } \\
r\end{array}$ & $\begin{array}{l}\text { Owner } \\
\text { of coins }\end{array}$ & $\begin{array}{l}\text { Analy } \\
\text { Face }\end{array}$ & $\begin{array}{l}M \\
n\end{array}$ & $\mathrm{Fe}$ & $\mathrm{Ni}$ & $\mathrm{Cu}$ & $\mathrm{Zn}$ & Mo & $\mathrm{Ag}$ & $\mathrm{Au}$ & $\mathrm{Pb}$ & $\mathrm{Bi}$ & $\begin{array}{l}\text { Weigh } \\
t(g)\end{array}$ & $\begin{array}{l}\text { Diamete } \\
\mathrm{r}(\mathrm{mm})\end{array}$ & Result \\
\hline 5 & $\begin{array}{l}\text { Maurice } \\
\text { Tiberius }\end{array}$ & $\begin{array}{l}\text { Collecto } \\
r\end{array}$ & Obv. & $\begin{array}{l}N \\
D\end{array}$ & $\begin{array}{l}0 \\
16\end{array}$ & $\begin{array}{l}\mathrm{N} \\
\mathrm{D}\end{array}$ & $\begin{array}{l}9, \\
06\end{array}$ & $\begin{array}{l}0, \\
23\end{array}$ & $\begin{array}{l}0, \\
01 \\
7\end{array}$ & $\begin{array}{l}7, \\
73\end{array}$ & $\begin{array}{l}82 \\
66\end{array}$ & $\begin{array}{l}0, \\
04\end{array}$ & $\begin{array}{l}0, \\
11\end{array}$ & 1,58 & 18 & Fake \\
\hline 5 & $\begin{array}{l}\text { Maurice } \\
\text { Tiberius }\end{array}$ & $\begin{array}{l}\text { Collecto } \\
r\end{array}$ & Rev. & $\begin{array}{l}N \\
D\end{array}$ & 0,8 & $\begin{array}{l}0, \\
02\end{array}$ & $\begin{array}{l}10 \\
96\end{array}$ & $\begin{array}{l}0, \\
25\end{array}$ & $\begin{array}{l}0, \\
02 \\
1\end{array}$ & $\begin{array}{l}7 \\
94\end{array}$ & $\begin{array}{l}79 \\
79 \\
\end{array}$ & $\begin{array}{l}0, \\
12\end{array}$ & $\begin{array}{l}0, \\
11\end{array}$ & & & Fake \\
\hline 6 & $\begin{array}{l}\text { Maurice } \\
\text { Tiberius }\end{array}$ & $\begin{array}{l}\text { Collecto } \\
r\end{array}$ & Obv. & $\begin{array}{l}N \\
D\end{array}$ & $\begin{array}{l}0 \\
33\end{array}$ & $\begin{array}{l}N \\
D\end{array}$ & $\begin{array}{l}6 \\
64\end{array}$ & $\begin{array}{l}0, \\
19\end{array}$ & $\begin{array}{l}0, \\
01 \\
5\end{array}$ & $\begin{array}{l}7, \\
91\end{array}$ & $\begin{array}{l}84 \\
\text { ' } \\
77\end{array}$ & $\begin{array}{l}0, \\
04\end{array}$ & $\begin{array}{l}0, \\
11\end{array}$ & 1,59 & 18 & Fake \\
\hline 6 & $\begin{array}{l}\text { Maurice } \\
\text { Tiberius }\end{array}$ & $\begin{array}{l}\text { Collecto } \\
r\end{array}$ & Rev. & $\begin{array}{l}\text { N } \\
D\end{array}$ & $\begin{array}{l}0 \\
17\end{array}$ & $\begin{array}{l}N \\
D\end{array}$ & $\begin{array}{l}9 \\
12\end{array}$ & $\begin{array}{l}0, \\
2\end{array}$ & $\begin{array}{l}0 \\
02 \\
7\end{array}$ & $\begin{array}{l}8, \\
03\end{array}$ & $\begin{array}{l}82 \\
38\end{array}$ & $\begin{array}{l}0, \\
56\end{array}$ & $\begin{array}{l}0, \\
02\end{array}$ & & & Fake \\
\hline 7 & $\begin{array}{l}\text { Maurice } \\
\text { Tiberius }\end{array}$ & $\begin{array}{l}\text { Collecto } \\
r\end{array}$ & Obv. & $\begin{array}{l}N \\
D\end{array}$ & $\begin{array}{l}0 \\
12\end{array}$ & $\begin{array}{l}N \\
D\end{array}$ & $\begin{array}{l}10 \\
21\end{array}$ & $\begin{array}{l}0, \\
22\end{array}$ & $\begin{array}{l}0 \\
01 \\
8\end{array}$ & $\begin{array}{l}8, \\
09\end{array}$ & $\begin{array}{l}81 \\
17\end{array}$ & $\begin{array}{l}0, \\
06\end{array}$ & $\begin{array}{l}0, \\
11\end{array}$ & 1,40 & 17 & Fake \\
\hline 7 & $\begin{array}{l}\text { Maurice } \\
\text { Tiberius }\end{array}$ & $\begin{array}{l}\text { Collecto } \\
r\end{array}$ & Rev. & $\begin{array}{l}N \\
D\end{array}$ & $\begin{array}{l}0 \\
13\end{array}$ & $\begin{array}{l}0, \\
03\end{array}$ & $\begin{array}{r}10 \\
, 8\end{array}$ & $\begin{array}{l}0, \\
26\end{array}$ & $\begin{array}{l}0, \\
02\end{array}$ & 8 & $\begin{array}{l}80 \\
56\end{array}$ & $\begin{array}{l}0, \\
06\end{array}$ & $\begin{array}{l}0, \\
13\end{array}$ & & & Fake \\
\hline 8 & $\begin{array}{l}\text { Maurice } \\
\text { Tiberius }\end{array}$ & $\begin{array}{l}\text { Collecto } \\
r\end{array}$ & Obv. & $\begin{array}{l}N \\
D\end{array}$ & $\begin{array}{l}0 \\
54\end{array}$ & $\begin{array}{l}0, \\
02\end{array}$ & $\begin{array}{l}11 \\
08\end{array}$ & $\begin{array}{l}0, \\
24\end{array}$ & $\begin{array}{l}0 \\
02 \\
3\end{array}$ & $\begin{array}{l}7, \\
92\end{array}$ & $\begin{array}{l}80 \\
12 \\
12\end{array}$ & $\begin{array}{l}0, \\
06\end{array}$ & $\begin{array}{l}N \\
D\end{array}$ & 1,62 & 18 & Fake \\
\hline
\end{tabular}




\begin{tabular}{|c|c|c|c|c|c|c|c|c|c|c|c|c|c|c|c|c|}
\hline 8 & $\begin{array}{l}\text { Maurice } \\
\text { Tiberius }\end{array}$ & $\begin{array}{l}\text { Collecto } \\
r\end{array}$ & Rev. & $\begin{array}{l}N \\
D\end{array}$ & $\begin{array}{l}0 \\
72\end{array}$ & $\begin{array}{l}0, \\
02\end{array}$ & $\begin{array}{l}9, \\
63\end{array}$ & $\begin{array}{l}0, \\
32\end{array}$ & $\begin{array}{l}0, \\
01 \\
9\end{array}$ & $\begin{array}{l}8, \\
12\end{array}$ & $\begin{array}{l}81 \\
19\end{array}$ & $\begin{array}{l}0, \\
08\end{array}$ & $\begin{array}{l}N \\
D\end{array}$ & & & Fake \\
\hline 9 & $\begin{array}{l}\text { Maurice } \\
\text { Tiberius }\end{array}$ & $\begin{array}{l}\text { Collecto } \\
r\end{array}$ & Obv. & $\begin{array}{l}N \\
D\end{array}$ & $\begin{array}{l}0 \\
38\end{array}$ & $\begin{array}{l}0, \\
03\end{array}$ & $\begin{array}{l}11 \\
59\end{array}$ & $\begin{array}{l}0, \\
27\end{array}$ & $\begin{array}{l}0 \\
01 \\
9\end{array}$ & $\begin{array}{l}7 \\
86\end{array}$ & $\begin{array}{l}79 \\
74\end{array}$ & $\begin{array}{l}\mathrm{N} \\
\mathrm{D}\end{array}$ & $\begin{array}{l}0, \\
11\end{array}$ & 1,62 & 18 & Fake \\
\hline 9 & $\begin{array}{l}\text { Maurice } \\
\text { Tiberius }\end{array}$ & $\begin{array}{l}\text { Collecto } \\
r\end{array}$ & Rev. & $\begin{array}{l}N \\
D\end{array}$ & $\begin{array}{l}0 \\
32\end{array}$ & $\begin{array}{l}N \\
D\end{array}$ & $\begin{array}{l}10 \\
, 8\end{array}$ & $\begin{array}{l}0, \\
22\end{array}$ & $\begin{array}{l}0, \\
01 \\
8\end{array}$ & 8 & $\begin{array}{l}80 \\
58\end{array}$ & $\begin{array}{l}0, \\
06\end{array}$ & $\begin{array}{l}\mathrm{N} \\
\mathrm{D}\end{array}$ & & & Fake \\
\hline 10 & $\begin{array}{l}\text { Maurice } \\
\text { Tiberius }\end{array}$ & $\begin{array}{l}\text { Collecto } \\
r\end{array}$ & Obv. & $\begin{array}{l}N \\
D\end{array}$ & \begin{tabular}{|l|}
0 \\
08 \\
6
\end{tabular} & $\begin{array}{l}0, \\
03\end{array}$ & $\begin{array}{l}6, \\
69\end{array}$ & $\begin{array}{l}0 \\
19\end{array}$ & $\begin{array}{l}0, \\
01 \\
5\end{array}$ & $\begin{array}{l}8 \\
26\end{array}$ & $\begin{array}{l}84 \\
, 7\end{array}$ & $\begin{array}{l}0, \\
04\end{array}$ & $\begin{array}{l}\mathrm{N} \\
\mathrm{D}\end{array}$ & 1,64 & 18 & Fake \\
\hline 10 & $\begin{array}{l}\text { Maurice } \\
\text { Tiberius }\end{array}$ & $\begin{array}{l}\text { Collecto } \\
r\end{array}$ & Rev. & $\begin{array}{l}N \\
D\end{array}$ & $\begin{array}{l}0 \\
07 \\
8\end{array}$ & $\begin{array}{l}N \\
D\end{array}$ & $\begin{array}{l}8 \\
35\end{array}$ & $\begin{array}{l}0, \\
21\end{array}$ & $\begin{array}{l}0, \\
12\end{array}$ & $\begin{array}{l}8 \\
49\end{array}$ & $\begin{array}{l}82 \\
82 \\
82\end{array}$ & $\begin{array}{l}0, \\
04\end{array}$ & $\begin{array}{l}N \\
D\end{array}$ & & & Fake \\
\hline 11 & $\begin{array}{l}\text { Maurice } \\
\text { Tiberius }\end{array}$ & $\begin{array}{l}\text { Collecto } \\
r\end{array}$ & Obv. & $\begin{array}{l}N \\
D\end{array}$ & 0,3 & $\begin{array}{l}N \\
D\end{array}$ & $\begin{array}{l}11 \\
26\end{array}$ & $\begin{array}{l}0, \\
24\end{array}$ & $\begin{array}{l}0 \\
19\end{array}$ & $\begin{array}{l}8, \\
05\end{array}$ & $\begin{array}{l}80 \\
\text { ' }\end{array}$ & $\begin{array}{l}0, \\
06\end{array}$ & $\begin{array}{l}\mathrm{N} \\
\mathrm{D}\end{array}$ & 1,67 & 18 & Fake \\
\hline 11 & $\begin{array}{l}\text { Maurice } \\
\text { Tiberius }\end{array}$ & $\begin{array}{l}\text { Collecto } \\
r\end{array}$ & Rev. & $\begin{array}{l}N \\
D\end{array}$ & 1 & $\begin{array}{l}0, \\
02\end{array}$ & $\begin{array}{l}11 \\
26\end{array}$ & $\begin{array}{l}0, \\
22\end{array}$ & $\begin{array}{l} \\
02 \\
1\end{array}$ & $\begin{array}{l}7, \\
99\end{array}$ & $\begin{array}{l}79 \\
42\end{array}$ & $\begin{array}{l}0, \\
07\end{array}$ & $\begin{array}{l}\mathrm{N} \\
\mathrm{D}\end{array}$ & & & Fake \\
\hline 12 & $\begin{array}{l}\text { Maurice } \\
\text { Tiberius }\end{array}$ & $\begin{array}{l}\text { Collecto } \\
r\end{array}$ & Obv. & $\begin{array}{l}N \\
D\end{array}$ & $\begin{array}{l}0 \\
44\end{array}$ & $\begin{array}{l}N \\
D\end{array}$ & $\begin{array}{l}10 \\
53\end{array}$ & $\begin{array}{l}0, \\
28\end{array}$ & $\begin{array}{l}0, \\
01 \\
6\end{array}$ & $\begin{array}{l}7, \\
89\end{array}$ & $\begin{array}{l}80 \\
64\end{array}$ & $\begin{array}{l}0, \\
64\end{array}$ & $\begin{array}{l}0, \\
11\end{array}$ & 1,53 & 17,5 & Fake \\
\hline 12 & $\begin{array}{l}\text { Maurice } \\
\text { Tiberius }\end{array}$ & $\begin{array}{l}\text { Collecto } \\
r\end{array}$ & Rev. & $\begin{array}{l}N \\
D\end{array}$ & $\begin{array}{l}0 \\
29\end{array}$ & $\begin{array}{l}N \\
D\end{array}$ & $\begin{array}{l}8 \\
54\end{array}$ & $\begin{array}{l}0, \\
22\end{array}$ & $\begin{array}{l}0 \\
01 \\
6\end{array}$ & $\begin{array}{l}8 \\
31\end{array}$ & $\begin{array}{l}82 \\
58\end{array}$ & $\begin{array}{l}0, \\
03\end{array}$ & $\begin{array}{l}\mathrm{N} \\
\mathrm{D}\end{array}$ & & & Fake \\
\hline 13 & $\begin{array}{l}\text { Maurice } \\
\text { Tiberius }\end{array}$ & $\begin{array}{l}\text { Collecto } \\
r\end{array}$ & Obv. & $\begin{array}{l}N \\
D\end{array}$ & $\begin{array}{l}0, \\
02\end{array}$ & $\begin{array}{l}N \\
D\end{array}$ & $\begin{array}{l}7, \\
98\end{array}$ & $\begin{array}{l}0, \\
02\end{array}$ & $\begin{array}{l}0 \\
01 \\
7\end{array}$ & $\begin{array}{l}7 \\
88\end{array}$ & $\begin{array}{l}83 \\
66\end{array}$ & $\begin{array}{l}0, \\
04\end{array}$ & $\begin{array}{l}N \\
D\end{array}$ & 1,52 & 18 & Fake \\
\hline 13 & $\begin{array}{l}\text { Maurice } \\
\text { Tiberius }\end{array}$ & $\begin{array}{l}\text { Collecto } \\
r\end{array}$ & Rev. & $\begin{array}{l}0, \\
03\end{array}$ & $\begin{array}{l}1, \\
19\end{array}$ & $\begin{array}{l}0, \\
03\end{array}$ & $\begin{array}{l}8, \\
31\end{array}$ & $\begin{array}{l}0, \\
23\end{array}$ & $\begin{array}{l}0, \\
01 \\
6\end{array}$ & $\begin{array}{l}8 \\
09\end{array}$ & $\begin{array}{l}82 \\
02\end{array}$ & $\begin{array}{l}0, \\
08\end{array}$ & $\begin{array}{l}N \\
D\end{array}$ & & & Fake \\
\hline 14 & $\begin{array}{l}\text { Maurice } \\
\text { Tiberius }\end{array}$ & $\begin{array}{l}\text { Collecto } \\
r\end{array}$ & Obv. & $\begin{array}{l}N \\
D\end{array}$ & $\begin{array}{l}0 \\
11\end{array}$ & $\begin{array}{l}0, \\
02\end{array}$ & 11 & $\begin{array}{l}0, \\
23\end{array}$ & $\begin{array}{l}0, \\
02 \\
4\end{array}$ & $\begin{array}{l}8, \\
08\end{array}$ & $\begin{array}{l}80 \\
49\end{array}$ & $\begin{array}{l}0, \\
06\end{array}$ & $\begin{array}{l}\mathrm{N} \\
\mathrm{D}\end{array}$ & 1,46 & 17 & Fake \\
\hline 14 & $\begin{array}{l}\text { Maurice } \\
\text { Tiberius }\end{array}$ & $\begin{array}{l}\text { Collecto } \\
r\end{array}$ & Rev. & $\begin{array}{l}N \\
D\end{array}$ & $\begin{array}{l}0 \\
19\end{array}$ & $\begin{array}{l}N \\
D\end{array}$ & $\begin{array}{l}9 \\
46\end{array}$ & $\begin{array}{l}0, \\
22\end{array}$ & $\begin{array}{l}0, \\
02 \\
1\end{array}$ & $\begin{array}{l}8, \\
01\end{array}$ & $\begin{array}{l}82 \\
05\end{array}$ & $\begin{array}{l}0, \\
05\end{array}$ & $\begin{array}{l}\mathrm{N} \\
\mathrm{D}\end{array}$ & & & Fake \\
\hline 15 & $\begin{array}{l}\text { Maurice } \\
\text { Tiberius }\end{array}$ & $\begin{array}{l}\text { Collecto } \\
r\end{array}$ & Obv. & $\begin{array}{l}N \\
D\end{array}$ & ND & $\begin{array}{l}0, \\
02\end{array}$ & $\begin{array}{l}6, \\
43\end{array}$ & $\begin{array}{l}0, \\
15\end{array}$ & $\begin{array}{l}0, \\
01 \\
2\end{array}$ & $\begin{array}{l}7, \\
99\end{array}$ & $\begin{array}{l}85 \\
23\end{array}$ & $\begin{array}{l}0, \\
05\end{array}$ & $\begin{array}{l}0, \\
12\end{array}$ & 1,58 & 18 & Fake \\
\hline 15 & $\begin{array}{l}\text { Maurice } \\
\text { Tiberius }\end{array}$ & $\begin{array}{l}\text { Collecto } \\
r\end{array}$ & Rev. & $\begin{array}{l}0, \\
33\end{array}$ & $\begin{array}{l}0 \\
03 \\
9\end{array}$ & $\begin{array}{l}0, \\
03\end{array}$ & $\begin{array}{l}6, \\
45\end{array}$ & $\begin{array}{l}0, \\
21\end{array}$ & $\begin{array}{l}0, \\
01 \\
3\end{array}$ & 8 & $\begin{array}{l}85 \\
16\end{array}$ & $\begin{array}{l}0, \\
03\end{array}$ & $\begin{array}{l}\mathrm{N} \\
\mathrm{D}\end{array}$ & & & Fake \\
\hline
\end{tabular}




\begin{tabular}{|c|c|c|c|c|c|c|c|c|c|c|c|c|c|c|c|c|}
\hline 16 & $\begin{array}{l}\text { Maurice } \\
\text { Tiberius }\end{array}$ & $\begin{array}{l}\text { Collecto } \\
r\end{array}$ & Obv. & $\begin{array}{l}N \\
D\end{array}$ & $\begin{array}{l}0 \\
32\end{array}$ & $\begin{array}{l}0, \\
02\end{array}$ & $\begin{array}{l}10 \\
65\end{array}$ & $\begin{array}{l}0, \\
26\end{array}$ & $\begin{array}{l}0, \\
01 \\
2\end{array}$ & $\begin{array}{l}7, \\
95\end{array}$ & $\begin{array}{l}80 \\
73\end{array}$ & $\begin{array}{l}0, \\
06\end{array}$ & $\begin{array}{l}N \\
D\end{array}$ & 1,63 & 18 & Fake \\
\hline 16 & $\begin{array}{l}\text { Maurice } \\
\text { Tiberius }\end{array}$ & $\begin{array}{l}\text { Collecto } \\
r\end{array}$ & Rev. & $\begin{array}{l}N \\
D\end{array}$ & $\begin{array}{l}0 \\
35\end{array}$ & $\begin{array}{l}0, \\
03\end{array}$ & $\begin{array}{l}11 \\
12\end{array}$ & $\begin{array}{l}0, \\
25\end{array}$ & $\begin{array}{l}, \\
02 \\
4\end{array}$ & $\begin{array}{l}8, \\
02\end{array}$ & $\begin{array}{l}80 \\
\text { ' }\end{array}$ & $\begin{array}{l}\mathrm{N} \\
\mathrm{D}\end{array}$ & $\begin{array}{l}0 \\
12\end{array}$ & & & Fake \\
\hline & & Avarage & & $\begin{array}{l}0 \\
18\end{array}$ & $\begin{array}{l}0, \\
35\end{array}$ & $\begin{array}{l}0, \\
02\end{array}$ & $\begin{array}{l}9 \\
49\end{array}$ & $\begin{array}{l}0, \\
22\end{array}$ & $\begin{array}{l}0, \\
02 \\
9\end{array}$ & $\begin{array}{l}8, \\
02\end{array}$ & $\begin{array}{l}81 \\
\text { ' } \\
77\end{array}$ & $\begin{array}{l}0, \\
1\end{array}$ & $\begin{array}{l}0 \\
1\end{array}$ & & & \\
\hline $2-1$ & $\begin{array}{l}\text { Maurice } \\
\text { Tiberius }\end{array}$ & $\begin{array}{l}\text { Museu } \\
\mathrm{m}\end{array}$ & Obv. & $\begin{array}{l}N \\
D\end{array}$ & $\begin{array}{l}0 \\
17\end{array}$ & $\begin{array}{l}\mathrm{N} \\
\mathrm{D}\end{array}$ & $\begin{array}{l}0 \\
36\end{array}$ & $\begin{array}{l}\mathrm{N} \\
\mathrm{D}\end{array}$ & ND & $\begin{array}{l}1, \\
58\end{array}$ & $\begin{array}{r}97 \\
, 9\end{array}$ & $\begin{array}{l}\mathrm{N} \\
\mathrm{D}\end{array}$ & $\begin{array}{l}\mathrm{N} \\
\mathrm{D}\end{array}$ & 2,24 & 21 & $\begin{array}{l}\text { Authenti } \\
\text { c }\end{array}$ \\
\hline $2-1$ & $\begin{array}{l}\text { Maurice } \\
\text { Tiberius }\end{array}$ & $\begin{array}{l}\text { Museu } \\
\mathrm{m}\end{array}$ & Rev. & $\begin{array}{l}\mathrm{N} \\
\mathrm{D}\end{array}$ & $\begin{array}{l}0 \\
09\end{array}$ & $\begin{array}{l}N \\
D\end{array}$ & $\begin{array}{l}0 \\
34\end{array}$ & $\begin{array}{l}N \\
D\end{array}$ & ND & $\begin{array}{l}1, \\
58\end{array}$ & $\begin{array}{l}97 \\
99\end{array}$ & $\begin{array}{l}\mathrm{N} \\
\mathrm{D}\end{array}$ & $\begin{array}{l}\mathrm{N} \\
\mathrm{D}\end{array}$ & & & $\begin{array}{l}\text { Authenti } \\
\mathrm{C}\end{array}$ \\
\hline $\begin{array}{l}214 \\
- \\
8 / 6- \\
89\end{array}$ & $\begin{array}{l}\text { Maurice } \\
\text { Tiberius }\end{array}$ & $\begin{array}{l}\text { Museu } \\
\mathrm{m}\end{array}$ & Obv. & $\begin{array}{l}N \\
D\end{array}$ & $\begin{array}{l}0 \\
08 \\
7\end{array}$ & $\begin{array}{l}N \\
D\end{array}$ & $\begin{array}{l}0 \\
1\end{array}$ & $\begin{array}{l}N \\
D\end{array}$ & ND & $\begin{array}{l}N \\
D\end{array}$ & $\begin{array}{l}99 \\
82\end{array}$ & $\begin{array}{l}N \\
D\end{array}$ & $\begin{array}{l}N \\
D\end{array}$ & 2,19 & 20 & $\begin{array}{l}\text { Authenti } \\
\text { c }\end{array}$ \\
\hline $\begin{array}{l}214 \\
- \\
8 / 6- \\
89\end{array}$ & $\begin{array}{l}\text { Maurice } \\
\text { Tiberius }\end{array}$ & $\begin{array}{l}\text { Museu } \\
\mathrm{m}\end{array}$ & Rev. & $\begin{array}{l}N \\
D\end{array}$ & 0,1 & $\begin{array}{l}N \\
D\end{array}$ & $\begin{array}{l}0, \\
11\end{array}$ & $\begin{array}{l}\mathrm{N} \\
\mathrm{D}\end{array}$ & ND & $\begin{array}{l}N \\
D\end{array}$ & $\begin{array}{l}99 \\
79\end{array}$ & $\begin{array}{l}N \\
D\end{array}$ & $\begin{array}{l}N \\
D\end{array}$ & & & $\begin{array}{l}\text { Authenti } \\
\text { C }\end{array}$ \\
\hline & & Avarage & & & $\begin{array}{l}0, \\
11\end{array}$ & & $\begin{array}{l}0, \\
22\end{array}$ & & & $\begin{array}{l}1, \\
58\end{array}$ & $\begin{array}{l}98 \\
88\end{array}$ & & & & & \\
\hline
\end{tabular}

Table 3: P-EDXRF analysis of modern gold

\begin{tabular}{|l|l|l|l|l|}
\hline & $\% \mathrm{Cu}$ & $\% \mathrm{Zn}$ & $\% \mathrm{Mo}$ & $\% \mathrm{Au}$ \\
\hline Modern gold & 8,8 & 0,15 & 0,019 & 91,07 \\
\hline Modern gold & 8,7 & 0,18 & 0,027 & 91,08 \\
\hline Modern gold & 7 & 0,14 & 0,017 & 92,84 \\
\hline Modern gold & 7,1 & 0,13 & 0,013 & 92,76 \\
\hline Modern gold & 6,7 & 0,11 & 0,015 & 93,16 \\
\hline Modern gold & 6,8 & 0,13 & 0,015 & 93,1 \\
\hline Modern gold & 6,6 & 0,1 & 0,014 & 93,25 \\
\hline Modern gold & 6,6 & 0,11 & 0,016 & 93,32 \\
\hline Modern gold & 6,6 & 0,14 & 0,015 & 93,25 \\
\hline Modern gold & 8,9 & 0,19 & 0,017 & 90,91 \\
\hline Modern gold & 8,6 & 0,2 & 0,015 & 91,14 \\
\hline Avarage & 7,5 & 0,14 & 0,017 & 92,35 \\
\hline
\end{tabular}




\begin{tabular}{|c|c|c|c|c|c|c|c|c|c|}
\hline Analysis No & $\begin{array}{l}\% \\
\mathrm{Cu}\end{array}$ & $\begin{array}{l}\% \\
\text { Sn }\end{array}$ & $\begin{array}{l}\% \\
\mathrm{Fe}\end{array}$ & $\begin{array}{l}\% \\
\mathrm{~Pb}\end{array}$ & $\begin{array}{l}\% \\
\mathrm{Zn}\end{array}$ & $\begin{array}{l}\% \\
\mathrm{Ni}\end{array}$ & $\begin{array}{l}\% \\
\mathrm{Bi}\end{array}$ & $\begin{array}{l}\% \\
\mathrm{Sb}\end{array}$ & $\begin{array}{l}\% \\
\mathrm{Rh}\end{array}$ \\
\hline 2 & 50.89 & 7.25 & 0.26 & 38.04 & ND & ND & 0.27 & 0.33 & 0.078 \\
\hline 3 & 63.85 & 14.39 & 0.54 & 20.71 & ND & 0.026 & 0.17 & 0.22 & ND \\
\hline 4 & 63.09 & 14.05 & 0.29 & 21.46 & ND & ND & ND & ND & ND \\
\hline 5 & 60.07 & 13.62 & 0.36 & 24.07 & ND & 0.034 & 0.18 & 0.26 & 0.056 \\
\hline 6 & 36.68 & 7.91 & 0.37 & 48.50 & ND & ND & 0.27 & 0.29 & 0.072 \\
\hline 7 & 37.39 & 9.15 & 0.22 & 46.01 & ND & ND & 0.27 & 0.28 & 0.065 \\
\hline 8 & 61.84 & 14.78 & 0.25 & 21.42 & ND & 0.024 & 0.015 & 0.23 & 0.045 \\
\hline 9 & 60.82 & 11.96 & 1.84 & 22.20 & 0.10 & ND & ND & ND & ND \\
\hline 10 & 49.82 & 11.43 & 8.02 & 22.46 & 1.27 & 0.22 & 0.24 & ND & ND \\
\hline 11 & 42.39 & 10.69 & 0.22 & 41.44 & ND & ND & 0.20 & 0.28 & 0.062 \\
\hline 12 & 53.87 & 11.29 & 0.24 & 30.75 & ND & ND & 0.021 & 0.25 & 0.063 \\
\hline 13 & 49.87 & 8.64 & 0.38 & 36.91 & ND & ND & 0.22 & 0.26 & 0.071 \\
\hline 14 & 51.77 & 10.97 & 0.26 & 34.15 & ND & ND & 0.16 & 0.26 & 0.058 \\
\hline 15 & 49.91 & 12.40 & 0.38 & 33.65 & ND & 0.038 & 0.24 & 0.29 & 0.057 \\
\hline 16 & 65.78 & 11.74 & 0.39 & 20.95 & ND & ND & 0.16 & 0.16 & ND \\
\hline 17 & 50.77 & 11.04 & 3.54 & 28.35 & 0.16 & ND & 0.18 & ND & ND \\
\hline 19 & 63.34 & 18.53 & 0.44 & 16.45 & ND & 0.020 & ND & 0.18 & ND \\
\hline 20 & 54.02 & 12.48 & 0.26 & 29.14 & ND & ND & 0.17 & 0.27 & 0.068 \\
\hline 21 & 48.15 & 15.40 & 0.18 & 32.13 & ND & ND & 0.17 & 0.20 & 0.047 \\
\hline
\end{tabular}

